\title{
Popper och marxismen. Några tillrättalägganden av vanliga missuppfattningar
}

\author{
INGVAR JOHANSSON
}

\section{Poppers berömmelse}

Karl Popper (1902-1994) blev genom sin bok Det öppna sambället och dess fiender (1945) känd långt utanför kretsen av filosofer, och så småningom en ikon för försvaret av öppna samhällen. I England blev han 1965 adlad för sin intellektuella insats. Inom vetenskapsfilosofin gjorde han sig redan under mellankrigstiden känd, då som kritiker av de logiska positivisterna. Han accepterade deras fundamentala problemformulering: hur kan vi på ett enkelt sätt skilja vetenskap från metafysik? Men hans svar - med den falsifierbarhetsprincip Popper formulerat - hade en helt annan och mindre fördömande karaktär än positivisternas varianter av sin verifierbarhetsprincip. Han ansåg att metafysik kan vara meningsfull och vara ett nödvändigt förstadium till nya vetenskapliga teorier.

Både Poppers politiska filosofi och hans vetenskapsfilosofi är mycket generella till sin karaktär, men båda har också uttryckligen som mål att diskreditera marxismen. Det är nästan enbart om förhållandet mellan Popper och marxismen som den här notisen handlar. Hållbarheten i Poppers eller marxistiskt tänkande ventileras inte. Jag är mycket väl beläst vad gäller både Popper och marxismen, och har bestämda åsikter om vad som är rimligt och orimligt i respektive fall. Men här är inte platsen att argumentera kring dessa saker. I det avslutande femte avsnittet framhåller jag emellertid - utan argumentation - en åsikt som Popper faktiskt delar med några välkända marxister. 


\section{Poppers avgränsning av marxismen}

I. Popper och den vilje-betonande marxismen. Det är lätt att få uppfattningen att Popper diskuterat all tidig marxism, men så är inte fallet. Det är endast Andra internationalens deterministiska marxism - den klassiska marxismen - han befattar sig med. Enligt denna kan man med säkerhet säga att kapitalismen är ett nödvändigt förstadium till socialism, och att kapitalismen när den väl mognat är dömd att gå under och ersättas av socialism. Popper är övertygad om att alla deterministiska världsåskådningar är felaktiga, och att människan har ett visst mått av fri vilja. Ingen determinism kan vara korrekt, och alltså inte heller den klassiska marxismens. Han diskuterar över huvud taget inte filosofin bakom Lenins marxism, vilken av andra samtida framstående marxister kritiserades för subjektivism och voluntarism. Den oortodoxe italienske marxisten och (efter I92I) kommunistledaren Antonio Gramsci hyllade på julafton I9I7 i en artikel i socialistpartiets tidning den ryska revolutionen som "en revolution mot Karl Marx 'Kapitalet'”. Popper såg den som en vederläggning av marxismen.

2. Popper och austromarxismen. Popper växte upp och levde i Wien till I934 (han var tillfälligtvis i England I935-1936, fick 1937 en tjänst i Nya Zeeland och 1946 en tjänst i London). Han hade god kännedom om och stor sympati för många av det österrikiska socialdemokratiska partiets verksamheter i det dåtida så kallade röda Wien. Trots detta så lyser i Poppers skrifter ledarnas reformistiska och demokratiska austromarxism (livaktig ca 1918-1934) märkligt nog helt med sin frånvaro. Biografen Malachi Haim Hacohen skriver i Karl Popper - The Formative Years, 1902-1945 (2000): "Uppenbarligen läste han ingen marxistisk litteratur efter 1922 och var inte bekant med austromarxisternas teoretiska arbeten" (s. 327). När han skrev Det öppna samhället och dess fiender tittade han dock återigen på mycket av vad han läst före 1922.

3. Sammanfattningsvis. Den oortodoxa marxismen från I9IO- och I920-talen har Popper aldrig diskuterat. Det är en missuppfattning att han kritiskt granskat all tidig marxism. 


\section{Popper och marxismens vetenskaplighet}

Som inledningsvis sagts, gjorde sig Popper på 1930-talet ett filosofiskt namn genom sin falsifierbarhetsprincip. Ibland gav han den mycket hårda och distinkta formuleringar, som att en teori är vetenskaplig endast om dess företrädare på förhand kan ange när observerade empiriska data skulle få dem att överge teorin. Men efter hand blev formuleringarna innehållsligt tunnare och tunnare. Till slut krävde falsifierbarhetsprincipen bara att en empirisk vetenskaplig teoribyggnad måste på något sätt i princip kunna stöta på data som inte stämmer med teorin. I slutet på 1970-talet slutar han att använda termen. Jag misstänker att han i tysthet också hade övergivit själva principen.

I Poppers skrifter före 70-talet kan man hitta ställen både där han säger att marxismen inte är falsifierbar och följaktligen ovetenskaplig, och ställen där han säger att marxismen är falsifierad och följaktligen vetenskaplig, om än falsk. Motsäger han då sig själv? Svaret är "nja". Låt mig förklara.

Popper anser att vetenskapsmän som tror på en teori som mött empiriska data som strider mot teorin - det vill säga teorin ser ut att vara falsifierad - är tillåtna att med hjälp av hjälphypoteser skapa en mer eller mindre modifierad teorihelhet som inte är falsifierad. Men bara på ett villkor. Hjälphypoteserna får inte bryta mot de metodregler $\mathrm{i}$ vilka Popper bäddat in sin falsifierbarhetsprincip. Med ett övergripande uttryck, de får inte vara ad hoc. Hans åsikt om marxismen är att den klassiska marxismen blivit falsifierad, och att marxister har räddat den med hjälp av ad hoc-hypoteser.

Noga besett betyder detta att teoribyggnader, marxismen inkluderad, aldrig i sig kan bryta mot falsifierbarhetsprincipen, det är egentligen bara forskare som använder ad hoc-hypoteser som bryter mot den. Här uppstår två problem för Poppers syn på marxismen. För det första, hur kan han veta att det inte finns framtida hjälphypoteser som inte är ad hoc och som kan rädda marxismen? Svar: detta diskuterar han aldrig. För det andra, hur noga har han kontrollerat att marxisternas förmenta ad hoc-hypoteser verkligen bryter mot hans metodregler? Svar: han förlitar sig helt på ytlig intuition. Jag citerar mig själv: "Popper bara påstår 
att marxismen är falsifierad eller bryter mot hans metodregler. Han visar det inte" (A Critique of Karl Popper's Methodology, I975, s. II7).

Det i dag förmodligen mest använda och omfattande filosofilexikonet i världen är internetverket The Stanford Encyclopedia of Philosophy. Under uppslagsordet "Karl Popper” står det i både deras första (1997) och senaste (20I8) presentation av honom: "Marxismen kan inte längre avfärdas som 'ovetenskaplig' bara därför att dess försvarare räddade teorin från falsifiering genom att modifiera den (ty i allmänna termer, visar det sig, är ett sådant tillvägagångssätt en fullt respektabel vetenskaplig praktik)."I

Det är en missuppfattning att Popper visat att den klassiska marxismen ofrånkomligen är ovetenskaplig.

\section{Poppers sanningsbegrepp och marxismens}

Den som börjar reflektera över sanningsbegreppet och startar med situationer där någon säger "Det har slutat regna”, varefter en tvivlande person går ut och tittar och säger "Minsann, sant var det", landar ofrånkomligen först i åsikten att sanning är en fråga om överensstämmelse eller korrespondens mellan påståenden och verklighet. Denna uppfattning, inom filosofi kallad korrespondensteorin om sanning, har från två diametralt olika filosofiska håll ansetts vara en nästan löjeväckande förenkling av hur sanning ska förstås. Kritiken kommer från både hegeliansk filosofi (marxistisk sådan inkluderad) och mainstream analytisk filosofi. Popper kan sägas ha varit en analytisk filosof, men han var aldrig en mainstream sådan, och han försvarar korrespondensteorin om sanning.

Ett av de problem en korrespondensteori har att lösa är hur man ska se på de empiriska vetenskapernas historiska utveckling. Inga teorier har hittills befunnits vara absolut sanna, och det är väl därför rimligt att tro att vetenskapen inte heller i framtiden kommer att hitta några. Eller? En ingrediens i Poppers lösningsförslag är att hävda att det vid sidan av sanningar finns sanningslikheter (också kallade approximativa sanningar

I. Från https://plato.stanford.edu/archives/wini997/entries/popper/ och https://plato. stanford.edu/archives/fall2or8/entries/popper/ (2 maj 2019). 
eller verisimilitudes). Vetenskapens utveckling ska förstås som att graden av sanningslikhet hos våra teorier ökar även om alla i en absolut mening är falska.

Länge (ca 1960-1980) trodde Popper att det var möjligt att konstruera ett mått med vars hjälp man kunde kvantifiera graden av sanningslikhet, men efter ett par decenniers kritisk diskussion accepterade han att detta är omöjligt. Många i övrigt till Poppers tänkande positiva filosofer drog då slutsatsen att hela begreppet om sanningslikhet måste överges, men inte Popper själv. Han sade att det informella icke-kvantifierade begreppet ändå är meningsfullt och viktigt att bevara.

Låt oss nu kasta ett öga på den icke-hegelianska marxismen. Den var precis lika medveten om vetenskapens utveckling som alla historiebetonande hegelianer var. Hos två av förgrundsfigurerna, Engels och Lenin, hittar man en klar distinktion mellan absoluta och relativa sanningar, där de senare har samma karaktär som Poppers informella begrepp om sanningslikheter. Se Engels Anti-Dühring (avsnitt I, kapitel IX) och Lenins Materialismen och empiriokriticismen (kapitel 2, avsnitt 4-6). Den grundläggande tankegången är att vetenskapen på mycket lång sikt förmodligen kommer att närma sig absoluta sanningar. En tankegång som vid ungefär samma tid också fördes fram av den amerikanska pragmatismens grundare, C.S. Peirce.

Det är en missuppfattning att det inte finns några viktiga filosofiska frågor där Popper och berömda marxister delat åsikt.

\section{Avslutande åsikt}

Den utpekade form av allmän kunskapsrealism som Popper och många marxister haft gemensam delar jag helt. Därmed inte sagt att jag ser den som stående över all filosofisk diskussion. Popper uppmärksammade inte alla problem som kritiska filosofer kan hitta hos begreppet om sanningslikhet, och för ett par år sedan tog jag mig an några av dessa; se uppsatsen "In Defense of the Notion of Truthlikeness" i Journal for General Philosophy of Science (volym 48, nr I 20I7, s. 59-69). Jag avslutar med ett citat från denna (s. 67): 
ARKIV | NR IO | KOMMENTAR

På grund av den oerhörda komplexiteten hos de fenomen som ger upphov till de nutida ekonomiska kriserna och den globala klimatkrisen, så tycker jag att ekonomer och klimatforskare är intill löje orimliga om de tror sig om att kunna hitta de sanna modellerna, och jag tycker de är skrupelfria om de söker forskningspengar i syfte att skapa rent fiktiva modeller. Allvarlig handlingsrelevant forskning kräver att begreppet om sanningslikhet tas på allvar. 


\title{
Lennart Olausson
}

\section{Demokrati \\ och socialism}

\author{
Austromarxismen \\ under mellankrigstiden
}

Den österrikiska socialdemokratin, den så kallade austromarxismen, intog under mellankrigstiden en självständig position mellan socialdemokrati och kommunism. Idéhistorikern Lennart Olausson introducerar här denna riktning genom att analysera den debatt om sambandet mellan demokrati och socialism som fördes mellan två förgrundsgestalter, Max Adler och Otto Bauer.

\section{ARkiv}

»Läs mer om boken på www.arkiv.nu« 


\section{ATT STUDERA}

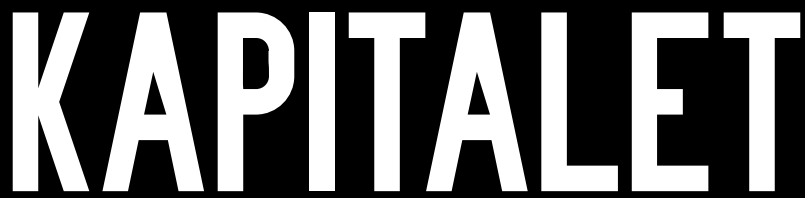

FÖRSTA BOKEN

\section{MATS LINDBERG}

I Att studera Kapitalet tar Mats Lindberg (tidigare Dahlkvist) fasta på Kapitalet betraktad som samhällsvetenskaplig teori: Vad handlar teorin om? Hur är teorin uppbyggd? Hur förhåller den sig till allmän historieteori, empirisk samhällsforskning och praktisk politik? Boken är uppbyggd som en textkommentar och studiehandledning som tar läsaren genom Kapitalets första bok sida för sida, kapitel för kapitel. Som en röd tråd löper en kritik mot tre inflytelserika marxistiska tolkningstraditioner (den sovjetiska, den hegelianska kapitallogiken och Althusserskolan) och boken avslutas med en kritisk granskning av filosofen Karl Poppers Marxläsning.

Arkivs nya utgåva är ett nytryck av denna klassiska doktorsavhandling från 1978. Hur författaren i dag ser på Kapitalets teori framgår av hans inledning till Arkivs sjätte och sjunde upplagor av Kapitalets första bok 2013 och 2018.

Ny utgåva, Arkiv förlag 2013, 665 sidor 